\title{
Immunochemical Assays for Determination of Organophosphorus Pesticides in Milk
}

\author{
Yavor Ivanov and Tzonka Godjevargova* \\ Prof. dr A. Zlatarov University, Bulgaria
}

Submission: April 10, 2019; Published: April 22, 2019

*Corresponding author: Tzonka Godjevargova, Department of Biotechnology, Prof. dr A. Zlatarov University, Burgas, Bulgaria

\begin{abstract}
The detection of pesticide residues is an important task in ensuring the safety of milk. In the last decade, organophosphorus insecticides have been used, but they also pose a serious risk because of their high toxicity. For fast screening of milk, immunochemical methods of analysis are appropriate. Enzyme-linked immunosorbent assay is the most common assay mode and base of many commercialized assay kits. Residues of some organophosphorus compounds in milk and dairy products determined by ELISA are shown. For fast screening of pesticides, the lateral flow strips are also described. The advantages of a new developed method MNPs-based immunoassay for determination of phosphorus pesticides in milk was described and some publications were represented. In recent years, simultaneous identification of more than one pesticide is increasingly perceptual, that way the examples for multi-immunoassays for determination of organophosphorus pesticides was presented.

Keywords: Organophosphorus pesticides; Milk; Immunoassay; ELISA; Lateral test; MNPs; Multi-assays

Abbreviations: DDT: dichloro diphenyl trichloroethane; ELISA: enzyme-linked immunosorbent assay; FLISA: fluorescent-linked immunosorbent assay; FPIA: Fluorescence polarization immuno-analysis; HPLC: high performance liquid chromatography; IFA: immunofluorescent assay; MNPs: magnetic nanoparticles; MRL: maximum residue limits; OPP: organophosphorus pesticides
\end{abstract}

\section{Introduction}

Milk and dairy products are widely used food products which are being consumed by people of different age groups. In this regard, the quality and safety of raw milk is an important issue $[1,2]$. The detection of pesticide residues is an important task in ensuring the safety of milk. The use of organochloride pesticide like dichloro diphenyl trichloroethane (DDT) and hexachlorocyclohexane $(\mathrm{HCH})$ was banned. However, the residual effects are still causing problems [3-5]. The residues of DDT persist in the environment for long periods and enter the food chain. In the last decade, organophosphorus insecticides (OPP) and carbamyl derivatives have been used that are relatively easy to degrade in the environment but also pose a serious risk because of their high toxicity. There are variety publications reporting organic compounds exceeding established maximum residue limits (MRL), for different OP pesticides, like fenthion, dichlorvos, methyl parathion, chlorpyrifos, and malathion in milk [6-8]. Melgar et al. [7] founded that the frequency of total samples containing detectable levels of OPP residues was $6.73 \%$ in total milk and $8.67 \%$ in raw milk. The highest percentage incidence measured was for dichlorvos (5.78\%), followed by coumaphos $(2.06$ $\%$ ), and parathion methyl (0.83\%). Salas et al. [8] described that approximately $39.6 \%$ of the pasteurized Mexican milk samples contained detectable levels of OP pesticide residues. Eight samples contained residues exceeding established maximum residue limits (MRL). They found that the OP pesticides present in these samples were dichlorvos, phorate, chlorpyrifos, and chlorfenvinphos). OP pesticides are strong cholinesterase inhibitors and they are like neurotransmitters for acetylcholinesterase, butyrylcholinesterase and pseudocholinesterase. When these enzymes are inhibited, acetylcholine accumulates in the neurons of the muscle nodes or synapses and changes the natural path of the nervous impulse. Acetylcholine accumulation causes a number of diseases like Alzheimer's disease and Parkinsonian disorders, and also many other degenerative diseases $[9,10]$.

Pesticide analysis is performed by liquid, gas and high performance liquid chromatography (HPLC), and HPLC along with Mass Spectrometry [11,12]. These methods are very suitable for monitoring toxic pesticides but have a number of disadvantages: expensive, time-consuming to prepare samples, require well-trained personnel, and are not adapted to conduct on-site and (on time) real-time analysis. For fast screening of milk, immunochemical methods of analysis [13] are appropriate. They 
are simple, fast, cheap, sensitive methods, provide real-time and time-based analysis, and do not require costly instrumentation. In addition, the immunoassay is also suitable for the analysis of milk, since milk samples can be analyzed after simple pretreatment such as dilution or protein precipitation.

\section{Immunochemical Methods}

Immunochemical methods are based on the reaction between the antigen (the pesticides studied) and the respectively antibody specific, which is very selective and rapid [14]. Since pesticides are small molecules, they cannot be detected by sandwich immunoassay. A competitive method should be used whereby the antigen in the sample competes with the labeled pesticide to bind to the antibody [15]. From immunochemical methods, the largest application for the determination of organophosphorus pesticides is the enzyme-linked immunosorbent assay (ELISA) and the immunofluorescent assay (IFA).

\section{ELISA and FLISA}

A significant number of ELISA assays were developed to identify different organophosphorus pesticides [16]. Analyzes are sensitive and detect very low concentrations of pesticides. Enzyme-linked immunosorbent assay (ELISA) is the most common assay mode and base of many commercialized assay kits. The preparation of monoclonal and polyclonal antibody against organophosphorus pesticides, and the antigen-enzyme conjugate synthesis, is the very important task [17-20]. The most common markers for those conjugates are the enzymes horseradish peroxidase and alkaline phosphatase. Quantification of the target analytes is based on corresponding substrate color change. Residues of some organophosphorus compounds in milk and dairy products determined by ELISA are shown in Table 1.

Table 1: Representative examples of ELISA for determination of Organophosphorus pesticide.

\begin{tabular}{|c|c|c|c|}
\hline \multicolumn{1}{|c|}{ Pesticides } & \multicolumn{1}{c}{ Antibody } & Linear Range & Reference \\
\hline Parathion & $\mathrm{p}$ & $0.1-5 \mu \mathrm{g} / \mathrm{L}$ & {$[21]$} \\
\hline Parathion & $\mathrm{p}$ & $0.2 \mu \mathrm{L} / \mathrm{L}$ & {$[22]$} \\
\hline Paraoxon & $\mathrm{m}$ & $10-100 \mu \mathrm{g} / \mathrm{mL}$ & {$[23]$} \\
\hline Paraoxon & $\mathrm{p}$ & $28-275 \mu \mathrm{g} / \mathrm{L}$ & {$[24]$} \\
\hline Paraoxon & $\mathrm{p}$ & $0.03 \mu \mathrm{g} / \mathrm{L}-275 \mathrm{mg} / \mathrm{L}$ & {$[25]$} \\
\hline Acephate & $\mathrm{P}$ & $5-140 \mathrm{ng} / \mathrm{mL}$ & {$[16]$} \\
\hline dichlorvos & $\mathrm{p}$ & $0.01-5 \mathrm{ng} / \mathrm{mL}$ & {$[26]$} \\
\hline paraoxon & $\mathrm{p}$ & $0.01-5 \mathrm{ng} / \mathrm{mL}$ & {$[26]$} \\
\hline
\end{tabular}

In recent years, a number of analyzes for pesticides in milk have been done based on fluorescent-linked immunosorbent assay (FLISA) [21-24]. This method is highly sensitive, because combined selectivity of antibody and sensitivity of fluorescent marker [25,26]. Different fluorescent markers are used: organic fluorescent dyes, fluorescent marker proteins, green fluorescent proteins, quantum dots [14]. ELISA and FLISA are simple and low cost methods, but analysis is multi-stage, requires multiple washing and takes a long time (Figure 1).

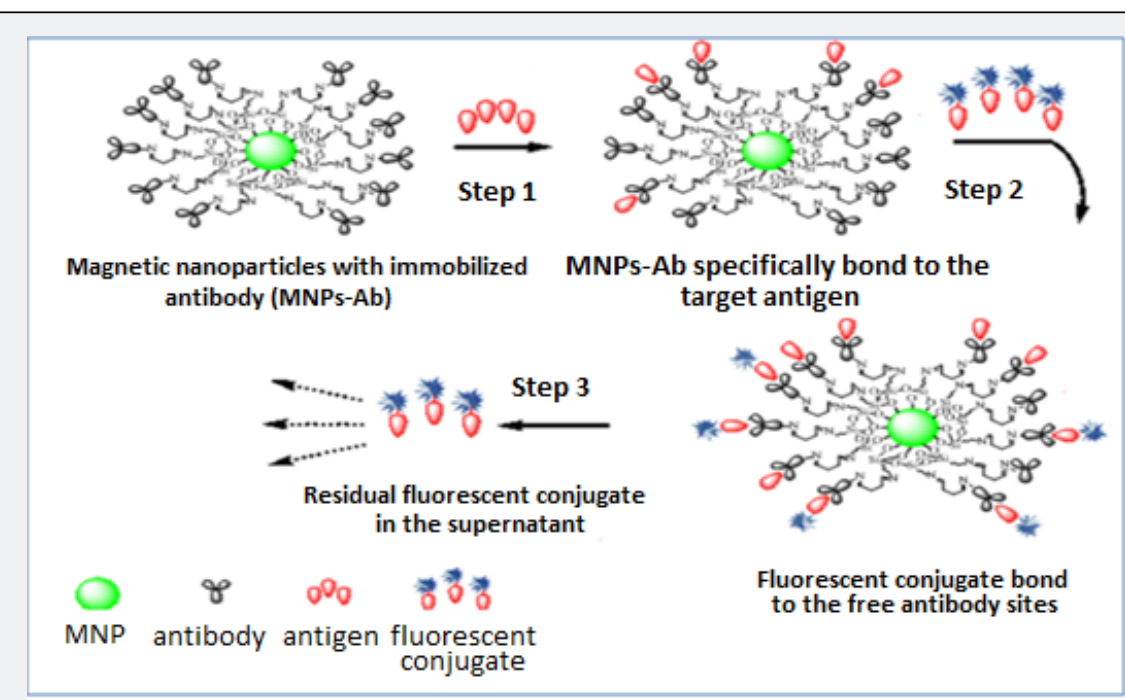

Figure 1: Scheme of the competitive MNP-based FIA.

\section{Lateral Flow Strips}

For fast screening of pesticides, the lateral flow strips are also used, but they are less sensitive and inaccurate. Lateral flow tests are also known as lateral flow immunochromatographic assays. The lateral flow strips are based on a competitive analysis. Unlabeled antigen and competitive antigen-marker are transported by the flow onto a nitrocellulose membrane, and they are competing for coupling with antibody immobilized onto the membrane [27]. The label most commonly used in immunochromatographic assay is colloidal gold, enzyme, magnetic nanoparticles [28]. The lateral flow strips are able to detect low pesticide concentrations. Their low detection limit is in the range of $\mathrm{ng} / \mathrm{mL}$, but often have false results. Residues of some organophosphorus compounds determined by lateral flow tests are shown in Table 2 [29-32]. 


\section{Journal of Dairy \& Veterinary Sciences}

Table 2: Representative examples of Lateral flow strips for determination of Organophosphorus pesticide.

\begin{tabular}{|c|c|c|c|c|}
\hline Pesticide & Marker & Samples & LOD & Reference \\
\hline fenitrothion & $\mathrm{Er}^{3+}$ & Food & $2 \mathrm{ng} / \mathrm{mL}$ & [29] \\
\hline Endosulfan & Gold nanoparticles & Agricultural products & $10 \mu \mathrm{g} / \mathrm{L}$ & {$[30]$} \\
\hline Methyl parathion & $\mathrm{Er}^{3+}$ & Food & $2 \mathrm{ng} / \mathrm{mL}$ & [29] \\
\hline parathion & $\mathrm{Er}^{3+}$ & Food & $2 \mathrm{ng} / \mathrm{mL}$ & \\
\hline Endosulfan & HRP & Agricultural products & $1 \mu \mathrm{g} / \mathrm{L}$ & [30] \\
\hline Methyl parathion & Gold nanoparticles & - & $8 \mathrm{ng} / \mathrm{mL}$ & [31] \\
\hline chlorpyrifos & Gold nanoparticles & Agricultural products & $10 \mathrm{ng} / \mathrm{mL}$ & [29] \\
\hline Methyl paraoxon & $\mathrm{Fe}_{3} \mathrm{O}_{4}$ & Food & $1.7 \mathrm{ng} / \mathrm{mL}$ & [32] \\
\hline
\end{tabular}

\section{FPIA and MNPs based IFA}

The IFA for pesticide determining does not draw back from the sensitivity of the ELISA method but does not require repeated washing and is a faster method [33]. Fluorescence polarization immuno-analysis (FPIA) is quick and applicable method. There many publications about OP pesticide detection. Anna Yu. Kolosova, et al. [34] was developed and optimized monoclonal antibody for the detection of parathion-methyl (PM). PM concentration determinable by the FPIA ranged from 25 to 10000 ppb. The detection limit was $15 \mathrm{ppb}$. Xu et al. [35] make the FPIA which detect 5 OPs simultaneously with a limit of detection below $10 \mathrm{ng} / \mathrm{mL}$. Heterogeneous IFA is preferable to homogeneous as it provides a more stable test, due to the immobilization of antibodies onto solid supports [36]. Application of nanoparticles as carriers increases the degree of immobilization of the antibody enhances the sensitivity of the immunoassay and preserves the activity of the immobilized antibody over time [37]. Particularly suitable for this purpose are magnetic nanoparticles (MNPs), since due to the applied magnetics separation accelerates and facilitates the conduct of the assay, reducing the interference of the interfering components in the milk sample and preserves the activity of the immobilized antibody over time [38]. MNPs have a high specific surface area and provide good contact between the immobilized antibody and the antigen and correspondingly high rate of immunoreaction. The principle of the method is based on competitive analysis. The target antigen and antigen-fluorescent dye conjugate compete for coupling to antibody immobilized onto MNPs (Table 3).

Table 3: Representative examples of MNPs based FIA for determination of Organophosphorus pesticide.

\begin{tabular}{|c|c|c|c|}
\hline Pesticides & Antibody & Linear Range & Reference \\
\hline Paraoxon & polyclonal & $2-300 \mathrm{ng} / \mathrm{mL}$ & {$[42]$} \\
\hline Dichlorvos & polyclonal & $5-300 \mathrm{ng} / \mathrm{mL}$ & {$[42]$} \\
\hline $\begin{array}{c}\text { Paraoxon }+ \\
\text { Dichlorvos }\end{array}$ & polyclonal & $10-400 \mathrm{ng} / \mathrm{mL}$ & {$[42]$} \\
\hline $\begin{array}{c}\text { Paraoxon }+ \\
\text { Dichlorvos }\end{array}$ & $\begin{array}{c}\text { Multi- } \\
\text { polyclonal }\end{array}$ & $5-300 \mathrm{ng} / \mathrm{L}$ & {$[43]$} \\
\hline Chlorpyrifos & polyclonal & $0.27-17.36 \mu \mathrm{g} / \mathrm{mL}$ & {$[44]$} \\
\hline Quinalphos & polyclonal & $0.13-10.34 \mu \mathrm{g} / \mathrm{mL}$ & {$[44]$} \\
\hline
\end{tabular}

At the first step, OPP containing sample is added to MNPs with immobilized antibody. Then, fluorescent conjugate (OPPfluorescent dye) is added and the conjugate is coupled to the non-occupied binding sites of the antibody. The MNP are collected with a permanent magnet. After that, the fluorescence intensity of the uncoupled conjugate (OPP-fluorescent dye) in the supernatant is measured. The excess of the conjugate is directly proportional to the OPP concentration in the sample. On this principle have been developed assays for the detection of ochratoxin, aflatoxin M1, enterotoxin A, and antibiotics in milk [38-41]. There are few publications about MNP-based immunoassay for the determination of phosphorus pesticides in milk [42-44].

\section{Multi-Immunoassays}

Testing several pesticides simultaneously in one sample is a very perceptual analysis. In recent years, simultaneous identification of more than one pesticide [45] is increasingly perceptual. To achieve this, it is possible to increase the number of antibodies that recognize individual antigens in one sample. A more economical alternative, however, is to create a single antibody that is able to identify several analytes in a single test and which is termed a broad-specific antibody. First, multihapten antigen was prepared by sequentially conjugating haptens of four different pesticides (chlorpyrifos, triazophos, carbofuran and parathion methyl) to the carrier protein bovine serum albumin (BSA) [46]. An antibody with wide cross reactivity is then obtained.

For example, Liang et al. [47,48] synthesized a common hapten of several 0, 0-dimethyl organophosphorus pesticides to produce a broad-spectrum antibody. The hapten is conjugated to bovine albumin (BSA) to produce an immunogen. Rabbits were immunized with the resulting immunogen and polyclonal antisera was produced against each of the antigens.

A common, broadly specific enzyme-linked immunosorbent assay for malathion, dimethoate, phenate, phosmet, methidathion, fenitrothion, methyl parathion and fenthion has been developed. The following IC50 values were determined under optimal conditions: $30 . \mu \mathrm{g} / \mathrm{L}$ for malathion, $28.9 \mu \mathrm{g} / \mathrm{L}$ for dimethoate, $88.3 \mu \mathrm{g} / \mathrm{L}$ for fentoate, $159.7 \mu \mathrm{g} / \mathrm{L}$ for phosmet, $191.7 \mu \mathrm{g} / \mathrm{L}$ for 
methidathion, $324.0 \mu \mathrm{g}$ / L for fenitrothion, $483.9 \mu \mathrm{g} / \mathrm{L}$ of methyl parathion and $788.9 \mu \mathrm{g} / \mathrm{L}$ for fenthion. Antibodies produced using the multi-hapten strategy have much lower affinities to analytes compared to antibodies derived from a single hapten. Probably this is due to a lower hapten-protein molecular ratio for each individual hapten in the multi-hapten immunogen compared with those immunogens that contained only a single hapten [46]. Mixing several single antigens together based on a certain proportion to form a multi-hapten immunogen was also used for the preparation of mixed antibodies [49,50]. Each hapten is coupled to a carrier protein individually and then the mixture is used as immunogen. In this case, a lower titer of multivariate was established as compared to the obtained antibodies with only one individual hapten.

\section{Conclusion}

The immunochemical assays for determination of organophosphorus pesticides are simple, fast, cheap, sensitive methods, provide real-time and time-based analysis, and do not require costly instrumentation. In addition, the immunoassay is also suitable for the analysis of milk, since milk samples can be analyzed after simple pretreatment such as dilution or protein precipitation. The developed MNPs based IFA and multi-assays are very perspective assays, suitable for determination of organophosphorus pesticides in milk.

\section{Acknowledgement}

This study was funded by National Scientific Fund Research Bulgaria (project Bulgaria/Russia 02/10-2018).

\section{References}

1. Griffiths M (2010) Improving the safety and quality of milk: Improving quality in milk products. (Edition 1), Woodhead Publishing, Sawston, Cambridge, UK, pp. 520.

2. Harley KG, Huen K, Aguilar Schall R, Holland NT, Bradman A, et al. (2011) Association of organophosphate pesticide exposure and paraoxonase with birth outcome in Mexican-American women. Plosone 6(8): e23923.

3. Shaker EM, Elsharkawy EE (2015) Organochlorine and organophosphorus pesticide residues in raw buffalo milk from agro-industrial areas in Assiut, Egypt. Environ Toxicol Pharmacol 39(1): 433-440.

4. Zhou S, Tang Q, Jin M, Liu W, Niu L, et al. (2014) Residues and chiral signatures of organochlorine pesticides in mollusks from the coastal regions of the Yangtze River Delta: Source and health risk implication. Chemosphere 114: 40-50.

5. Rengasamy P, Kantharimuthu A, Balaraman M, Sivanesan S (2016) Development of ELISA kit for the assay of dichlorodiphenyltrichloroethane in milk and milk products. Afr J Food Sci 10(3): 41-47.

6. Fagnani R, Beloti V, Battaglini A, Dunga K, Tamanini R (2011) Organophosphorus and carbamates residues in milk and feedstuff supplied to dairy cattle. Pesq Vet Bras 31(7): 598-602.

7. Melgar M, Santaeufemia M, Garcia MA (2010) Organophosphorus pesticide residues in raw milk and infant formulas from Spanish northwest. J Environ Sci Health B 45(7): 595-600.

8. Salas J, González M, Noa M, Pérez N, Díaz G, et al. (2003) Organophosphorus pesticide residues in Mexican commercial pasteurized milk. J Agric Food Chem 51(15): 4468-4471.
9. Aytenfsu S, Mamo G, Kebede B (2016) Review on chemical residues in milk and their public health concern in Ethiopia. J Nutr Food Sci 6(4): $1-11$.

10. Silva KC, Assis CR, Oliveira VM, Carvalho LB Jr, Bezerra RS (2013) Kinetic and physicochemical properties of brain acetylcholinesterase from the peacock bass (Cichla ocellaris) and in vitro effect of pesticides and metal ions. Aquat Toxicol 126: 191-197.

11. Niessen W, Manini P, Andreoli R (2006) Matrix effects in quantitative pesticide analysis using liquid chromatography-mass spectrometry. Mass Spectrom Rev 25(6): 881-899.

12. Hem L, Khay S, Choi J, Morgan E, Abd El-Aty A, et al. (2010) Determination of trichlorfon pesticide residues in milk via gas chromatography with $\mu$-electron capture detection and GC-MS. Toxicol Res 26(2): 149-155.

13. Akhtar S, Ahad K (2017) Pesticides residue in milk and milk products: Mini review. Pak J Anal Environ Chem 18(1): 37-45.

14. Xu F, Ren K, Yang Y, Guo J, Ma G, et al. (2015) Immunoassay of chemical contaminants in milk: A review. J Integr Agric 14(11): 2282-2295.

15. Bhadekar R, Pote S, Tale V, Nirichan B (2011) Developments in analytical methods for detection of pesticides in environmental samples. Am J Analyt Chem 2(8A): 1-15.

16. Lee JK, Ahn KC, Stoutamire DW, Gee SJ, Hammock BD (2003) Development of an enzyme-linked immunosorbent assay for the detection of the organophosphorus insecticide acephate. J Agric Food Chem 51(13): 3695-3703.

17. Liu Y, Lou Y, Xu D, Qian G, Zhang Q et al. (2009) Production and characterization of monoclonal antibody for class-specific determination of 0 , 0 -dimethyl organophosphorus pesticides and effect of heterologous coating antigens on immunoassay sensitivity. Microchem J 93(1): 36-42.

18. Xu ZL, Xie GM, Li YX, Wang BF, Beier RC, et al. (2009) Production and characterization of a broad-specificity polyclonal antibody for $\mathrm{O}$, 0-diethyl organophosphorus pesticides and a quantitative structureactivity relationship study of antibody recognition. Anal Chim Acta 647(1): 90-96.

19. Zhao F, Hu C, Wang H, Zhao L, Yang Z (2015) Development of a MAbbased immunoassay for the simultaneous determination of 0, 0-diethyl and 0,0 -dimethyl organophosphorus pesticides in vegetable and fruit samples pretreated with QuEChERS. Anal Bioanal Chem 407(30): 8959-8970.

20. Li X, Zhang H, Ji Y, Zheng Z, Bian Q et al. (2015) Immunochemical and molecular characteristics of monoclonal antibodies against organophosphorus pesticides and effect of hapten structures on immunoassay selectivity. Food Agric Immunol 216(1): 109-119.

21. Ferguson BS, Larkin KA (1994) Monitoring Parathion and Parathionmethyl in Ground, Surface and Rice Paddy Water with a Rapid and Sensitive Immunoassay. Book of Abstracts. Eighth IUPAC International Congress of Pesticide Chemistry. Washington, USA.

22. Wong J, Li Q, Hammock B, Seiber J (1991) Method for the analysis of 4-nitrophenol and parathion in soil using supercritical fluid extraction and immunoassay. J Agric Food Chem 39(10): 1802-1807.

23. Brimfield A, Lenz D, Graham C, Hunter K Jr (1985) Mouse monoclonal antibodies against paraoxon: potential reagents for immunoassay with constant immunochemical characteristics. J Agric Food Chem 33(6): 1237-1242.

24. Heldman E, Balan A, Horowitz O, Ben-Zion S, Torten M (1985) A novel immunoassay with direct relevance to protection against organophosphate poisoning. FEBS Lett 180(2): 243-248.

25. Hunter KW Jr, Lenz DE (1982) Detection and quantification of the organophosphate insecticide paraoxon by competitive inhibition enzyme immunoassay. Life Sci 30(4): 355-361. 
26. Yaneva M, Ivanov Y, Godjevargova T (2017) Preparation of polyclonal antibodies with application for an organophosphorus pesticide immunoassay. Anal Lett 50(8): 1-18.

27. Sajid M, Kawde AN, Daud M (2015) Designs, formats and applications of lateral flow assay: A literature review. J Saudi Chem Soc 19(6): 689705.

28. Anfossi L, Di Nardo F, Cavalera S, Giovannoli C, Baggiani C (2018) Multiplex lateral flow immunoassay: An overview of strategies towards high-throughput point-of-need testing. Biosensors (Basel) 9: 1.

29. Kim YA, Lee EH, Kim KO, Lee YT, Hammock BD, Lee HS (2011) Competitive immunochromatographic assay for the detection of the organophosphorus pesticide chlorpyrifos. Anal Chim Acta 693(1-2) 106-113.

30. Zhang C, Zhang Y, Wang S (2006) Development of multianalyte flowthrough and lateral-flow assays using gold particles and horseradish peroxidase as tracers for the rapid determination of carbaryl and endosulfan in agricultural products. J Agric Food Chem 54(7): 2502 2507.

31. Hua X, Yang J, Wang L, Fang Q, Zhang G, Liu F (2012) Development of an enzyme linked immunosorbent assay and an immunochromatographic assay for detection of organophosphorus pesticides in different agricultural products. Plosone 7(12): e53099.

32. Liu C, Jia Q Yang C, Qiao R, Jing L, et al. (2011) Lateral flow immunochromatographic assay for sensitive pesticide detection by using Fe304 nanoparticle aggregates as color reagents. Anal Chem 83(17): 6778-6784.

33. Wu S, Duan N, Gu H, Hao L, Ye H, et al. (2016) A review of the methods for detection of Staphylococcus aureus enterotoxins. Toxins (Basel) $8(7): 176$

34. Kolosova AY, Park JH, Eremin SA, Kang SJ, Chung DH (2003) Fluorescence polarization immunoassay based on a monoclonal antibody for the detection of the organophosphorus pesticide parathion-methyl. J Agric Food Chem 51(5): 1107-1114.

35. Xu ZL, Wang Q Lei HT, Eremin SA, Shen YD, Wang H, et al. (2011) A simple, rapid and high-throughput fluorescence polarization immunoassay for simultaneous detection of organophosphorus pesticides in vegetable and environmental water samples. Anal Chim Acta 708(1-2): 123-129.

36. Welch NG, Scoble JA, Muir BW, Pigram PJ (2017) Orientation and characterization of immobilized antibodies for improved immunoassays (Review). Biointerphases 12(2): 02 D301.

37. El-Ansary A, Faddah L (2010) Nanoparticles as biochemical sensors. Nanotechnol Sci Appl 3: 65-76.
38. Godjevargova T, Ivanov Y, Dinev D (2017) Multiplex fluorescent immunoassay device based on magnetic nanoparticles. AIP Conf Proc $1809(1)$.

39. Font H, Adrian J, Galve R, Estévez MC, Castellari M, Gratacós-Cubarsí M, et al. (2008) Immunochemical assays for direct sulfonamide antibiotic detection in milk and hair samples using antibody derivatized magnetic nanoparticles. J Agric Food Chem 56(3): 736-743.

40. Atanasova M, Vasileva N, Godjevargova T (2017) Determination of aflatoxin M1 in milk by a magnetic nanoparticle-based fluorescent immunoassay. Anal Lett 50(3): 452-469.

41. Becheva Z, Ivanov Y, Gabrovska K, Godjevargova T (2019) Rapid immunofluorescence assay for staphylococcal enterotoxin A using magnetic nanoparticles. Int J Food Sci Technol 54(3): 916-922.

42. Yaneva M, Ivanov Y, Todorov N, Godjevargova T (2018) Magneticnanoparticles-based fluorescent immunoassay for individual and simultaneous determination of dichlorvos and paraoxon in milk. Food Agric Immunol 29(1): 228-243.

43. Ivanov Y, Yaneva M, Godjevargova T, Zvereva E (2019) Immunofluorescence assay of pesticides on the base of immobilized multi-polyclonal antibody. Food Sci Appl Biotechnol 2(1): 46-53.

44. Hu Y, Shen G, Zhu H, Jiang G (2010) A class-specific enzyme-linked immunosorbent assay based on magnetic particles for multiresidue organophosphorus pesticides. J Agric Food Chem 58(5): 2801-2806.

45. Li YF, Sun YM, Beier R, Lei HT, Gee S, et al. (2017) Immunochemical techniques for multianalyte analysis of chemical residues in food and the environment: A review. TrAc-Trend Anal Chem 88: 25-40.

46. Wang ST, Gui WJ, Guo YR, Zhu GN (2007) Preparation of a multi-hapten antigen and broad specificity polyclonal antibodies for a multiple pesticide immunoassay. Anal Chim Acta 587(2): 287-292.

47. Liang Y, Liu XJ, Liu Y, Yu XY, Fan MT (2008) Synthesis of three haptens for the class-specific immunoassay of 0,0-dimethyl organophosphorus pesticides and effect of hapten heterology on immunoassay sensitivity. Anal Chim Acta 615(2): 174-183.

48. Liang Y, Liu Y, Zhu JF, Fan MT, Liu XJ (2008) Production of broad specificity anti-methoxyorganophosphorus pesticides antibody. Chinese J Anal Chem 36(5): 647-652.

49. Shi H, Li H, Hua X, Zheng Z, Zhu G, et al. (2014) Characterization of multihapten antigens on antibody sensitivity and specificity for parathion. Anal Lett 47(16): 2699-2707.

50. Zikos C, Evangelou A, Karachaliou CE, Gourma G, Blouchos P, et al. (2015) Commercially available chemicals as immunizing haptens for the development of a polyclonal antibody recognizing carbendazim and other benzimidazole-type fungicides. Chemosphere 119: S16-S20.

Your next submission with Juniper Publishers
will reach you the below assets
- Quality Editorial service
- Swift Peer Review
- Reprints availability
- E-prints Service
- Manuscript Podcast for convenient understanding
- Global attainment for your research
- Manuscript accessibility in different formats
( Pdf, E-pub, Full Text, Audio)
- Unceasing customer service
Track the below URL for one-step submission
https://juniperpublishers.com/online-submission.php

